\title{
THE EFFECT OF MINERAL SUPPLEMENTS ON RESORPTION IN THE DIGESTIVE TRACT OF CATTLE, WITH SPECIAL REFERENCE TO BOLUS ALBA
}

\author{
K. Roine, T. VARvikko, L. Lappalainen, and K. Östring \\ Department of Obstetrics and Gynecology, Hautjärvi; Department of Pharmacology, \\ College of Veterinary Medicine, Helsinki, Scientific Laboratories of Messrs. Lääke Oy. \\ Turku
}

Received December 2, 1965

The perfect composition of mineral mixtures in cattle feed is still a subject of investigation. On the basis of yield and diet, experiments with new combinations are continuing. Many factors, such as the quality of the mineral compounds used and the composition of the fodder, influence the resorption of the minerals. In order to achieve better mineral utilization, different supplements are added to the mixtures, e.g. adsorbating substances like Bolus alba. Previous experiments have shown Bolus alba to possess good feeding qualities. Brune $(1,2,3)$ has proved in experiments with rats and sheep that Bolus alba does not exert a negative influence on the resorption of fat-soluble vitamins. In experiments with pigs, Freese (4) has shown Bolus alba to improve the utilization of calcium and phosphorus. Wöhlbier (6) has demonstrated that fodder containing Bolus alba has a favourable influence on cattle suffering from a deficiency of tracer elements. In addition to this adsorbating quality, Bolus alba is considered to have a positive effect on the microorganisms of the digestive tract (5).

The object of the present work was to study the effects of Bolus alba on the resorption of phosphorus and carotenes in the digestive tract of cattle.

\section{Material and Methods}

Fourteen sexually mature heads of cattle of different ages and in different stages of production were used as experimental animals. They were divided into two groups so that both groups were as similar as possible with regard to the age 
of the animals. The groups were fed on different sides of the same manger. The cows of Group I, numbering 1-7, received mixture A and Group II, numbering 8-14, mixture B. Otherwise, both groups were given the same feeding:

Mixture A Ca $13.5 \%, \mathrm{P} 8.8 \%$, and Bolus alba $15 \%$

Mixture B Ca $23.5 \%$, P $8.8 \%$

Samples of blood and faeces of the animals were taken monthly for the determination of phosphorus, respectively phosphorus and carotenes. The experiment was started on October 1st, 1964. During the preliminary stage lasting one month (October), the animals were fed their respective mixtures, and the first samples were taken in November, 1964. The experiment lasted until May, 1965, i.e., till the end of the stabling period.

The blood samples were examined at the Department of Pharmacology, College of Veterinary Medicine, by the modified method of Fiske-Subbarow. The faeces samples were analysed by the Scientific Laboratories of Messrs. Lääke Oy, Turku. The molybdenum method of Lorenz-Neubauer was used for the analysis of phosphorus, and the spectrophotometer method of Peterson, Hughes \& Freeman for the determination of carotenes.

The blood samples were examined on the day of sampling while those of the faeces were analysed $1-2$ days after sampling.

Table 1. Values of inorganic phosphorus in blood serum $\mathrm{mg} / 100 \mathrm{ml}$.

\begin{tabular}{rrrrrrrr}
\hline $\begin{array}{c}\text { Animal } \\
\text { N:o }\end{array}$ & November & December & January & February & March & April & May \\
\hline & & & & & & & \\
1 & 4.8 & 6.1 & 5.6 & 5.1 & 5.4 & 6.4 & 6.6 \\
2 & 5.7 & 6.4 & 6.1 & 6.2 & 5.4 & 7.1 & 6.0 \\
3 & 6.0 & 6.0 & 5.3 & 5.3 & 4.8 & 5.1 & 6.2 \\
4 & 7.5 & 8.1 & 7.8 & 7.5 & 5.9 & 7.2 & 7.0 \\
5 & 4.9 & 8.4 & 7.6 & 6.5 & 7.3 & 7.1 & 7.1 \\
6 & 7.0 & 8.4 & 7.6 & 7.6 & $*)-$ & - & - \\
7 & 7.9 & 8.9 & 8.3 & 8.5 & 7.5 & 9.8 & $* *)-$ \\
8 & 6.1 & 6.1 & 6.5 & 6.5 & 6.3 & 6.9 & 7.1 \\
9 & 6.0 & 6.7 & 5.7 & 5.0 & 5.6 & 7.4 & 6.3 \\
10 & 4.8 & 6.3 & 5.4 & 4.6 & 5.1 & 5.6 & 5.1 \\
11 & 5.5 & 6.9 & 6.1 & 5.1 & 5.9 & 6.1 & 5.1 \\
12 & 7.0 & 6.8 & 7.2 & 5.5 & 5.6 & 5.4 & 6.0 \\
13 & 6.3 & 7.7 & 6.6 & 5.4 & 7.8 & 5.7 & 7.1 \\
14 & 6.2 & 7.6 & 7.6 & - & 5.5 & 4.0 & 6.6
\end{tabular}

*) Animal slaughtered in March.

**) Sample damaged during transportation. 
Table 2. Values of phosphorus in faeces $\mathrm{gr} / \mathbf{k g}$ dry matter.

\begin{tabular}{rrrrrrrr}
\hline $\begin{array}{c}\text { Animal } \\
\text { No. }\end{array}$ & November & December & January & February & March & April & May \\
\hline 1 & & & & & & \\
2 & 8.2 & 9.5 & 8.2 & 11.0 & 10.0 & 12.4 & 11.0 \\
3 & 11.5 & 10.4 & 8.7 & 10.0 & 8.1 & 10.8 & 11.3 \\
4 & 8.4 & 9.8 & 7.7 & 9.3 & 10.4 & 10.7 & 7.9 \\
5 & 8.2 & 7.4 & 8.9 & 7.8 & 7.0 & 7.7 & 12.7 \\
6 & 6.7 & 8.2 & 6.2 & 6.2 & 6.4 & 9.8 & 5.3 \\
7 & 7.6 & 6.8 & 6.3 & 6.7 & $*)-$ & - & - \\
8 & 12.3 & 10.3 & 7.5 & 6.3 & $* *)-$ & 12.2 & 5.6 \\
9 & 6.9 & 8.9 & 9.2 & 9.2 & 15.5 & 14.3 & 10.7 \\
10 & 9.2 & 12.7 & 9.9 & 11.0 & 8.1 & 10.3 & 10.0 \\
11 & 7.8 & 9.3 & 14.0 & 9.4 & 7.6 & 10.3 & 10.7 \\
12 & 6.2 & 7.7 & 7.3 & 7.9 & 6.6 & 11.1 & 8.9 \\
13 & 7.3 & 9.3 & 7.9 & 8.6 & 6.5 & 7.7 & 8.7 \\
14 & 6.8 & 8.8 & 6.0 & 10.3 & 7.6 & 13.2 & 7.4 \\
& 8.5 & 9.8 & 7.7 & 12.1 & 9.1 & 15.4 & 8.3 \\
\hline
\end{tabular}

*) Animal slaughtered in March.

**) Sample damaged during transportation.

Table 3. Values of carotene in faeces $\mathrm{gr} / \mathrm{kg}$ dry matter.

\begin{tabular}{rrrrrrrr}
\hline $\begin{array}{c}\text { Animal } \\
\text { N:o }\end{array}$ & November & December & January & February & March & April & May \\
\hline & & & & & & & \\
1 & & & & & & & \\
2 & 87.3 & 98.4 & 48.4 & 84.8 & 90.2 & 83.0 & 84.3 \\
3 & 99.8 & 105.5 & 48.8 & 123.0 & 129.9 & 83.1 & 77.5 \\
4 & 102.8 & 96.4 & 45.8 & 100.6 & 74.8 & 59.6 & 78.4 \\
5 & 150.6 & 135.8 & 72.6 & 114.8 & 89.1 & 81.0 & 104.1 \\
6 & $* *$ & 133.3 & 70.0 & 129.9 & 97.3 & 88.6 & 125.8 \\
7 & 151.1 & 112.1 & 53.6 & 136.2 & $*)-$ & - & - \\
8 & 137.6 & 96.7 & 59.6 & 146.5 & $* *)-$ & 89.7 & 148.9 \\
9 & 93.6 & 98.2 & 57.8 & 87.7 & 127.3 & 75.2 & 89.5 \\
10 & 98.1 & 101.7 & 44.3 & 92.8 & 70.7 & 137.5 & 92.8 \\
11 & 115.9 & 113.9 & 65.0 & 104.3 & 81.8 & 61.8 & 99.7 \\
12 & 132.4 & 108.3 & 64.5 & 112.7 & 66.4 & 50.0 & 79.8 \\
13 & 148.9 & 143.8 & 72.7 & 107.9 & 71.2 & 58.8 & 94.7 \\
14 & 127.6 & 131.0 & 51.4 & 105.2 & 121.6 & 100.9 & 99.1 \\
& 125.9 & 135.1 & 49.5 & 129.0 & 146.4 & 79.7 & 94.1 \\
\hline
\end{tabular}

*) Animal slaughtered in March.

**) Sample damaged during transportation.

\section{Results}

Tables $1-3$ show the values of phosphorus and carotenes during the entire length of the experiment while Table 4 gives the mean values of both groups. 


\section{Discussion}

The purpose of the present investigation was to find out whether the adsorbating qualities of Bolus alba might influence the resorption of phosphorus and carotenes in an unfavourable way.

Table 4. Mean values of experimental groups during the entire period of investigation.

\begin{tabular}{cccc}
\hline Group No. & $\begin{array}{l}\text { Values of phosphorus } \\
\text { in blood serum }\end{array}$ & $\begin{array}{l}\text { Values of phosphorus } \\
\text { in faeces }\end{array}$ & $\begin{array}{l}\text { Values of carotene } \\
\text { in faeces }\end{array}$ \\
\hline I & 6.7 & 8.8 & 98.3 \\
II & 6.1 & 9.3 & 96.3 \\
\hline
\end{tabular}

It is evident from Table 4 that the blood values of phosphorus of the animals in Group I are somewhat higher than those found in Group II; that the faeces values of phosphorus of the animals in Group II are in some degree higher than those found in Group I, and that in Group I, the mean carotene values of the faeces are a little higher than in Group II.

Judging by these results the reduction of the Ca-amount of the mineral mixture in favour of added Bolus alba, has not had any detrimental effects on the resorption of phosphorus and carotenes.

\section{$S u m m$ ary}

Fourteen sexually mature heads of cattle were divided into two groups; Group I receiving mineral mixture A, containing $15 \%$ of Bolus alba, while Group II were given mixture $\mathrm{B}$, containing no Bolus alba, but $10 \%$ more $\mathrm{Ca}$. Otherwise, both groups received the same feeding. Samples of blood and faeces of the animals were taken monthly for the determination of phosphorus, respectively phosphorus and carotenes. The experiment lasted one stabling period.

In Group I, the mean inorganic phosphorus values of the blood were $6.7 \mathrm{mg} / 100$ $\mathrm{ml}$. and in Group II, $6.1 \mathrm{mg} / 100 \mathrm{ml}$. The mean phosphorus values of the faeces were $8.8 \mathrm{gr} / \mathrm{kg}$ dry matter in Group I and in Group II, $9.3 \mathrm{gr} / \mathrm{kg}$ dry matter. The mean carotene values in Group I were $98.3 \mathrm{mg} / \mathrm{kg}$ dry matter and in Group II, $96.3 \mathrm{mg} / \mathrm{kg}$ dry matter. However, none of these differencies is statistically significant.

On the basis of the present investigation it can be concluded that Bolus alba exerts no detrimental influence on the resorption of phosphorus and carotenes in the digestive tract of cattle. 


\section{REFERENCES:}

(1) Brune, H. 1957. Zur Beeinflussung der Verdauung durch Adsorbentien. I Teil, Arch. f. Tierern. 2: 100 .

(2) - - 1952. Zur Beeinflussung der Verdauung durch Adsorbentien. Ibid. 3: 1. II Teil.

(3) - - 1955. Einfluss von erdigen Adsorbentien auf die Resorption. Ibid. 4: 335.

(4) Freese, H. H. 1958. Untersuchungen über den Calcium-Phosphor-, Magnesium- und Stickstoffumsatz des Ferkels in Beziehung zum Wachstum bei Muttermilch und Muttermilchersatz. Ibid $8: 330$,

(5) Streuter, A. 1959. Bolus alba - ein erdiges Adsorbens als Gemengteil der Mineralfutter. Futter und Fütterung 10:38.

(6) Wöhlbier, W. \& Kirchgessner, M. 1957. Kobaltmangel-Erscheinungen im Schwarzwald. Landwirtsch. Forsch. 10: 222.

\section{SELOSTUS :}

\section{KIVENNÅISSEOSTEN VAIKUTUKSESTA RESORPTIO-OLOSUHTEISIIN NAUTAELÄINTEN REHUNSULATUSKANAVASSA, ERIKOISESTI HUOMIOIDEN NIIDEN BOLUS ALBA-PITOISUUS}

\section{K. Roine, T. Varvikko, L. Lappalainen ja Kerttu Östring}

Eläinlääketieteellisen Korkeakoulun obstetriikan ja gynekologian laitoksesta, Hautjärvi, farmakologian laitoksesta, Helsinki, ja Lääke Oy:n Tieteellisestä Tutkimuslaboratoriosta, Turku

Neljätoista sukukypsää nautaeläintä jaettiin kahteen ryhmään. Ryhmä I sai kivennäisseosta A, jossa oli $15 \%$ Bolus albaa, ja ryhmä II seosta B, jossa ei ollut Bolus albaa mutta $10 \%$ enemmän Ca. Ruokinta muuten samanlainen. Kuukausittain otettiin eläimistä verinäytteet fosforimäärityksiä varten sekä lanta-näytteet fosforin ja karotiinien määritystä varten. Koe kesti yhden sisäruokintakauden ajan.

Ryhmässä I oli seerumin epäorgaanisen fosforin keskimääräinen arvo $6.7 \mathrm{mg} / 100 \mathrm{ml}$. ja II 6.1 $\mathrm{mg} / 100 \mathrm{ml}$. Fosforiarvot lannassa olivat keskimäärin ryhmässä I $8.8 \mathrm{gr} / \mathrm{kg}$ k.a. ja ryhmässä II 9.3 gr/kg k.a. Karotiiniarvot keskimäärin ryhmässä I $98.3 \mathrm{mg} / \mathrm{kg}$ k.a. ja ryhmässä II $96.3 \mathrm{mg} / \mathrm{kg}$ k.a. Erot eivät kuitenkaan ole tilastollisesti varmoja.

Suoritetun tutkimuksen perusteella voitaneen katsoa, ettei Bolus alballa ole ollut haitallista vaikutusta fosforin eikä karotiinien imeytymiseen nautaeläinten rehunsulatuskanavassa. 